\title{
Understanding older adults' labour market trajectories: a comparative gendered life course perspective
}

\author{
Diana Worts University of Toronto, Canada \\ dworts@chass.utoronto.ca

\begin{tabular}{ll}
\hline Laurie Corna & King's College London, UK \\
Amanda Sacker & University College London, UK \\
Anne McMunn & University College London, UK \\
Peggy McDonough & University of Toronto, Canada
\end{tabular}

(Received November $2015 \quad$ Revised April 2016) http://dx.doi.org/10.14301/llcs.v7i4.389

\section{Abstract}

The recent push to keep older adults in the labour force glosses over who is likely to follow what kind of employment trajectory and why. In this paper, we broaden understandings of later-life labour market involvement by applying a comparative gendered life course perspective. Our data come from the Survey of Health, Ageing and Retirement in Europe and the Health and Retirement Study (US), two representative panel studies of individuals aged 50-plus. Using a unique modeling strategy, we examine employment biographies for older women and men from four nations with diverse policy regimes (Germany, Italy, Sweden, and the US), along with their links to family experiences and earlier attachment to the labour force. We find that, in every nation, women prevail in groups representing a weak(er) attachment to the labour market and men in groups signifying a strong(er) attachment. However, this pattern is much stronger for Germany and Italy than for Sweden and the US. Similarly, both family experiences and prior employment matter more for later-life labour market involvement in Germany and Italy. Our findings demonstrate that older adults' employment trajectories are gendered; moreover, there is evidence that they are influenced by policies related not only to paid work but also to caregiving, and by those affecting not only current decisions but also those made earlier in the life course.

\section{Keywords}

Older adults; life course; employment; family; gender; welfare state; optimal matching

\section{Introduction}

In the wake of population ageing and the baby boom cohort's impending retirement, analysts have turned their attention to older adults' labour force participation (e.g., OECD, 2006). Yet, the dominant conceptual emphases-state-funded incomes that 'pull,' and workplace barriers that 'push,' older adults out of the labour force-often gloss over life course considerations that illuminate who is likely to follow what kind of later-life labour market trajectory and why (Cooke, 2006).

Studies framed by a gendered life course perspective offer a corrective. They focus on longterm outcomes, the continuity between experiences at younger and older ages, the role of family ties, and 
the influence of institutional contexts (Moen \& Flood, 2013). These factors especially shape the employment patterns of women and men (Gornick \& Meyers, 2006). Yet, studies of older adults' labour market trajectories and the social and institutional processes that shape them are surprisingly rare (Börsch-Supan, Hank, Jürges, \& Schröder, 2009). Most longitudinal research on later-life employment focuses on transitions-either withdrawal (e.g., Radl, 2013) or re-entry (e.g., Kail \& Warner, 2013). While transitional events are important, they are but one element in a succession of labour market experiences that characterise the later years (Bowlby, 2007). This suggests that older adults' employment patterns are best modeled as extended biographical sequences, using methods that take the entire series as the unit of analysis (Billari \& Piccarreta, 2005).

In this study, we draw on a gendered life course perspective, and begin to flesh out the what, who, and why of long-term patterns of later-life labour market involvement. Employing a unique modeling strategy that captures biographical sequences over ages 50-69, we examine their gendered correlates across four contrasting institutional contexts: Germany, Italy, Sweden, and the United States (US). We ask:

- How distributions across later-life labour market biographies differ for women and men in each country;

- Whether male-female differences in the distribution of these trajectories are the (gendered) outcome of family and prior work experiences; and

- How both these aspects vary across the four institutional contexts.

We begin with an outline of the gendered life course perspective, existing evidence, and our hypotheses. Following a description of our methods, the results section charts male-female differences in later-life labour market biographies for the four nations, then examines how family experiences and earlier attachment to the labour force contribute to these gender disparities. We conclude by discussing our findings and their policy implications.

\section{Background}

\section{The gendered life course}

Researchers increasingly argue that older adults' labour market involvement is best understood by drawing on a life course perspective (e.g., Alley, Putney, Rice, \& Bengtson, 2010). This entails a focus on individuals' long-term circumstances in a given domain, such as employment (Mayer, 2004). It also encompasses the notions of biographical continuity and linked lives-the ideas that older adults' labour market trajectories follow from their paid work experiences at younger ages (Han \& Moen, 1999a), and that those experiences are shaped by ties to family (Moen, 1996). Importantly, the division of labour by sex means that roles will often be gendered, at least earlier in the life course, with men assuming primary responsibility for breadwinning and women providing the bulk of care (Blossfeld \& Drobnič, 2001).

The life course perspective also emphasises that biographies are shaped by institutional contextsmost obviously, welfare regimes (Mayer, 2004). These can be distinguished by the relative roles of the state, markets, and families in providing life's necessities (Esping-Andersen, 1990), and the model of family life implied by that balance (Korpi, Ferrarini, \& Englund, 2013). The distinctions identified apply to the years when our sample members were in their prime working and childrearing years (Katz, 2010; Persky, 2011; Sundström, 2003). In corporatist regimes (typified by Germany), families are the primary providers of social welfare. The state supports a breadwinner-caregiver model of family life: full male employment with fairly generous benefits for periods of non-employment, and primary caregiving for women. Wives and mothers are assumed to work for pay only secondarily, if at all, and childcare spaces are limited in number and hours covered. In southern European nations (typified by Italy), breadwinnercaregiver families also play a central role in the provision of social welfare, leading to marked gender differences in employment (Siaroff, 1994). Social spending is generally low, and, at least historically, families have often maintained themselves as multigenerational households in which women care for one or more male breadwinners (Gal, 2010). In liberal regimes (typified by the US), social spending is also 
low, but the distribution of resources is left to the market. The state passively backs a market-oriented dual-earner model, in which the majority of individuals (male and female) work for pay throughout their lives despite a dearth of public supports for caregiving. Social democratic nations (typified by Sweden) are distinguished by the state's prominent role in the distribution of resources and care provision. They actively support a dual-earner model-offering comprehensive publicly-funded caregiving services, fairly generous benefits for periods of non-employment, flexible work arrangements, and better-quality part-time jobs to sustain caregivers' labour force attachment (Halldén, Gallie, \& Zhou, 2012). Table 1 (row 1) summarises these distinctions.

Welfare states are also distinguished by the extent to which their labour market policies aim to remove or retain older workers (Blossfeld, Buchholz, \& Hofäcker, 2006; Blossfeld, Buchholz, \& Kurz, 2011). (Table 1, row 2.) Again, the broad strokes of these approaches have remained quite stable during the years that affect our cohort (Blossfeld et al., 2006). Corporatist and southern regimes favour employment exit. High levels of wage replacement through public pensions and early retirement schemes-including, in Italy, relatively lenient access to illness/disability pensions for older workers (Beckstette, Lucchini, \& Schizzerotto, 2006)-make early withdrawal attractive. Because these regimes tend not to integrate women into the labour force earlier in the life course, the implications of exit strategies for women's later-life labour market involvement, or for gender differences in that regard, are unclear.

Social democratic and liberal regimes are oriented toward employment maintenance. This takes two forms. The public-induced strategies of social democratic regimes combine active labour market policies (e.g., retraining and job protection) with generous publicly-funded pensions, to foster labour force attachment until-but not necessarily beyondstate pension age. Nevertheless, relatively easy access to disability benefits has provided some older Swedish workers with an early exit route (Lindquist, 2006). The market-induced approaches of liberal regimes blend minimal labour market regulation with meagre public pensions that encourage some older adults to remain employed past state pension age and/or if their work histories are not strong. Moreover, for Americans in this cohort health care coverage has been tied to employment (or the receipt of social assistance/disability benefits). This may motivate many older workers to remain in the labour force until they qualify for Medicare at age 65. Both types of maintenance strategies also foster part-time work in later life. Public-induced approaches can include the option to 'phase out' while receiving a generous partial pension; in market-induced regimes, part-time work may reflect the combined influence of minimally regulated markets and financial need and/or the greater flexibility afforded those with more personal resources. 
Table 1: Institutional contexts for breadwinning/caregiving, and later-life labour market involvement

\begin{tabular}{|c|c|c|c|c|}
\hline & Germany & Italy & Sweden & US \\
\hline $\begin{array}{l}\text { Breadwinning \& } \\
\text { caregiving earlier in } \\
\text { the life course }{ }^{a}\end{array}$ & $\begin{array}{l}\text { - Families are primary } \\
\text { providers of social } \\
\text { welfare; state } \\
\text { supports are strong } \\
\text { - Breadwinner- } \\
\text { caregiver model of } \\
\text { family life } \\
\text { - Support for full } \\
\text { male employment; } \\
\text { fairly generous } \\
\text { benefits for periods } \\
\text { of non-employment } \\
\text { - Little/no direct } \\
\text { support for } \\
\text { mothers' (full-time) } \\
\text { employment }\end{array}$ & $\begin{array}{l}\text { - Families are primary } \\
\text { providers of social } \\
\text { welfare; state } \\
\text { supports are weak } \\
\text { - Breadwinner- } \\
\text { caregiver model of } \\
\text { family life } \\
\text { - Fairly ungenerous } \\
\text { benefits for periods } \\
\text { of (male) non- } \\
\text { employment } \\
\text { - Little/no support } \\
\text { for mothers' } \\
\text { employment }\end{array}$ & $\begin{array}{l}\text { - State plays a role in } \\
\text { social welfare } \\
\text { provision \& } \\
\text { employment } \\
\text { supports } \\
\text { - Publicly-oriented } \\
\text { dual-earner model } \\
\text { of family life }\end{array}$ & $\begin{array}{l}\text { - State's role in both } \\
\text { social welfare \& } \\
\text { employment } \\
\text { supports is } \\
\text { minimised } \\
\text { - Market-oriented } \\
\text { dual-earner model } \\
\text { of family life } \\
\text { - Passive promotion } \\
\text { of full adult } \\
\text { employment } \\
\text { - Ungenerous social } \\
\text { safety net } \\
\text { - Little/no public } \\
\text { support for family } \\
\text { responsibilities }\end{array}$ \\
\hline $\begin{array}{l}\text { Later-life labour } \\
\text { market } \\
\text { involvement }\end{array}$ & $\begin{array}{l}\text { - Employment exit: } \\
\text { high levels of wage } \\
\text { replacement through } \\
\text { public pensions and } \\
\text { attractive early } \\
\text { retirement schemes }{ }^{c} \\
\text { - Official retirement } \\
\text { age: } 65^{d} \\
\text { - Earliest retirement } \\
\text { age: } 63 \text { for men, } 60^{d} \\
\text { for women }\end{array}$ & $\begin{array}{l}\text { - Employment exit: } \\
\text { high levels of wage } \\
\text { replacement } \\
\text { through public } \\
\text { pensions and } \\
\text { attractive early } \\
\text { retirement } \\
\text { schemes }^{c} \\
\text { - } \text { Official retirement } \\
\text { age: } 60 \text { for men, } 55 \\
\text { for women }{ }^{d} \\
\text { - Earliest retirement } \\
\text { age: } 57 \text { (for men) }{ }^{d}\end{array}$ & $\begin{array}{l}\text { - Employment } \\
\text { maintenance } \\
\text { (public-induced): } \\
\text { generous public } \\
\text { pensions; only } \\
\text { moderate } \\
\text { incentives for early }^{\text {retirement }}{ }^{\mathrm{c}} \\
\text { - } \text { Official retirement }^{\text {age: } 65^{\mathrm{d}}} \\
\text { - Earliest retirement } \\
\text { age: } 61^{\mathrm{d}}\end{array}$ & $\begin{array}{l}\text { - Employment } \\
\text { maintenance } \\
\text { (market-induced): } \\
\text { low public } \\
\text { pensions; } \\
\text { few/moderate } \\
\text { incentives for early } \\
\text { retirement } \\
\text { - Official retirement } \\
\text { age: } 65^{\mathrm{d}} \\
\text { - Earliest retirement } \\
\text { age: } 62^{\mathrm{d}}\end{array}$ \\
\hline
\end{tabular}

\footnotetext{
${ }^{a}$ Adapted from Korpi (2000) and Trifiletti (1999: 54, 56).

b In a more recent article, Korpi, Ferrarini, and Englund (2013) label Sweden's model of family life "earner-carer," due to the introduction of policies designed to encourage male caregiving. However, these policies would not have applied during the years when our respondents were in their prime child-rearing years.

${ }^{\mathrm{c}}$ Adapted from Buccholz, Hofacker, and Blossfeld (2006).

${ }^{d}$ Data sources: Duval (2003: 35) and $\operatorname{OECD}(2005,2006,2009)$. There will be variation in some of these ages in some countries (e.g., Italy) based on individual work histories. State pension ages listed are those that apply to our birth cohort.
} 
Although broad approaches to older workers differ across welfare regimes, state pension ages for our cohort are generally 65 , with uptake possible in the early 60 s (table 1 , row 2 ). The exception is Italy, where both normal and early pension ages are lower-in the former case, especially for women.

The framework of Blossfeld and colleagues (2006, 2011) suggests that later-life labour market trajectories will vary cross-nationally despite similar state pension ages - though the extent and nature of gendering is unclear. Esping-Andersen-based typologies imply that institutional contexts may gender paid and family work earlier in the life course; but how this plays out at older ages is less apparent.

\section{Existing research}

Cross-sectional and time-series data show variations in older adults' labour force participation in line with welfare regime theories. Rates are lowest in Italy, followed by Germany, then the US, and highest in Sweden (OECD, 2011). In all four countries, participation is higher for older men than for their female counterparts; but the gap is largest in Italy, followed closely by Germany, intermediate in the US, and narrowest in Sweden (Kahn, 2010: 30). Among those in the labour force, women exit earlier than men in all four nations, although the gap is somewhat smaller in the US and Sweden than in Germany and Italy (OECD, 2011). Later working (ages 65-69) is least common in Germany and Italy, more frequent in Sweden, and relatively widespread in the US (OECD, 2011). Part-time work plays a significant role in the lives of older women (but not men) in Germany and Sweden (Morris \& Mallier, 2003), is rare for older Italians of both sexes (Morris \& Mallier, 2003), and is relatively common among older Americansespecially, but not exclusively, women (US Bureau of Labor Statistics, 2000).

These aggregate-level data cannot, however, reveal long-term biographical patterns or uncover their correlates and antecedents. Research using panel data provides clues, but tends to examine single transitions, such as retirement timing (e.g., Radl, 2013; Warner \& Hofmeister, 2006) or re-entry (e.g., Kail \& Warner, 2013; Pleau, 2010). This emphasis is problematic from a gender perspective, since it excludes anyone without a reasonably steady work history-that is, many women. By contrast, an approach based on extended labour market sequences-regardless of status at a given age-can include all older adults in all countries, and fully capture cross-national differences in the gendering of later-life labour market involvement.

Few studies consider the extended sequences of older adults; and we know of only one that models employment per se for any of the countries in our analysis. Han and Moen (1999b) assess work histories from age 30 to retirement, and identify five distinct biographies: delayed-entry, orderly, fast-track, steady part-time, and intermittent. Their study is, however, based on a small non-representative American sample, making their results difficult to generalise. In two loosely related studies, Fasang $(2010,2012)$ uses nationally representative data to analyse income source sequences of older Germans and Britons. She concludes that, in both countries, men tend to follow institutionalised pathways to retirement, while women predominate in part-time work and nonemployment trajectories. Although Fasang speculates that gendered family roles shape women's pathways, she does not test this hypothesis or investigate whether the influence of family experiences differs in the two countries.

Many studies explore the effects of family circumstances on older adults' employment or exit probabilities-typically focusing on current marital status. For Americans, being married decreases older women's attachment to the labour force (e.g., Moen \& Flood, 2013), but increases that of older men (e.g., Williamson \& McNamara, 2003). Being in a couple has no impact on the odds of employment for German men, but reduces them for German women; makes no difference for Swedish women, but increases employment for Swedish men; and reduces employment for Italian men and, particularly, Italian women (Ogg \& Renaut, 2007). However, the life course perspective's emphasis on long-term circumstances suggests that the critical factor may be marital (in)stability, rather than current marital status. Certainly, the loss of a partner ends or compromises the pooling of resources (Wilmoth \& Koso, 2002) and the gendering of breadwinning and caregiving, and might reasonably be expected to promote employment, especially for women.

There is some evidence on the influence of parenthood. Being a mother delays labour market 
withdrawal for German and American women, as does later age at the time of the first birth (Hank, 2004; Moen \& Flood, 2013; Pienta, 1999). Conclusions are mixed regarding the links between labour force participation and having dependent children at older ages. The association may be positive for men and negative for women (Dentinger \& Clarkberg, 2002; Pienta \& Hayward, 2002); negative for women only (Moen \& Flood, 2013; Szinovacz, DeViney, \& Davey, 2001); or nonexistent (Denaeghel, Mortelmans, \& Borghgraef, 2011). Importantly, though, results are for single countries (or do not test country interactions), and thus cannot reveal crossnational distinctions in effects. In one cross-national study, Hank and Korbmacher (2013) find that the positive association between being a mother and leaving employment in later life is specific to corporatist regimes for our cohort - although their sample was restricted to those with at least some paid work from age 50 .

Regardless, the notion of biographical continuity suggests that earlier work histories - themselves linked to family experiences - may be decisive. Among employed married Americans aged 50-75, men (but not women) with longer work histories are more likely to leave the labour market (Szinovacz \& DeViney, 2000). Older American women (married or not) are more likely to be in the labour force if they had fewer employment interruptions earlier in the life course, at least for the cohort born in the 1920s (Pienta, Burr, \& Mutchler, 1994).

These studies pertain to the US only. Contrasting institutional contexts mean that prior employment has varied cross-nationally, especially among women - implying that its impact on the gendering of laterlife labour market involvement may also vary. In Germany, long maternity leaves, a lack of childcare facilities, and a tax system favouring breadwinnercaregiver families have encouraged women to withdraw or work part-time after marrying or having children (Drobnič, Blossfeld, \& Rohwer, 1999; Hofäcker, Stoilova, \& Riebling, 2013; Sundstrom, 2003). For Italians, the combination of relatively low education, a lack of part-time work, an underdeveloped service sector, limited childcare, and strong norms around the sexual division of labour often persuaded women with family responsibilities to leave the labour force (Rydell, 2002; Sundström,
2003). In Sweden, where daycare spending has been high, work-family reconciliation policies relatively comprehensive, equal pay legislation long-standing, and the service sector large (Rovny, 2011: 341), women tended to remain employed during the prime childrearing years (Sundström, 2003). How this plays out at older ages is uncertain: Hank and Korbmacher (2013) conclude, based on data from 13 European countries, that length of prior employment is positively associated with the odds of leaving the labour force, but they do not consider gender differences, either within or between nations.

In sum, a number of gaps are evident in existing knowledge of older adults' labour market biographies. The emphasis on transitions underrepresents or excludes women; and the few studies that consider long-term trajectories do not focus on employment per se, are not generalisable, lack a comparative dimension, and/or do not take gender into account. Beyond this, comparative evidence on the roles of family and paid work experiences earlier in the life course is sparse, mixed, and not always available for both sexes. In what follows, we begin to flesh out these aspects of older adults' labour market biographies by testing four hypotheses:

Hypothesis 1: Distributions for later-life labour market biographies will be gendered-with men concentrated in more 'attached' (mostly full-time; shorter stretches of non-employment), and women in less 'attached' (stretches of part-time; longer periods of non-employment), trajectories.

Hypothesis 2: Male-female distinctions in later-life labour market biographies will be stronger in Germany and Italy than in Sweden and the US. This may be especially true for Italy, given the gender gap in pension eligibility.

Hypothesis 3a: Gender differences in older adults' employment trajectories will be partly attributable to gender-specific influences of family experiences over the life course. Hypothesis $3 b$ : The impact of family experiences will be stronger in Germany and Italy than in Sweden and the US. 
Hypothesis 4a: The gendering of older adults' labour market trajectories will be at least partly explained by gendered earlier attachment to the labour force. Hypothesis 4b: The explanatory power of work histories will be stronger in Germany and Italy than in Sweden and the US.

\section{Methods}

\section{Data}

Our data come from two nationally representative panel studies: the Survey of Health, Ageing and Retirement in Europe (SHARE); and the Health and Retirement Study (HRS) (Börsch-Supan \& Jürges, 2005; Heeringa \& Connor, 1995). Both surveys sample individuals aged 50+, and include detailed employment/activity histories, as well as key sociodemographic variables. SHARE covers more than 85,000 individuals from 21 countries, over a maximum, to date, of four waves: 2004/5, 2006/7, $2008 / 9$, and $2011 / 12$. We restrict analyses to those born in the 1930s or early 1940s (controlling for historical period and matching the HRS sample) and living in one of three countries of interest-(former West) Germany, Italy, and Sweden. HRS has interviewed more than 26,000 Americans aged 50+, biennially since 1992 and most recently in 2012. We use the original cohort, and only those who were ageeligible according to HRS criteria (born 1931-1941). From both studies, we select those with information on at least ten of the 20 possible labour market state variables over ages 50-69 ( $N=475$ for Germany, 935 for Italy, 654 for Sweden, and 8,832 for the US). And in each case, we utilise current and retrospective information on employment/activity start and end dates for all years in which respondents were aged 50-69 years, along with retrospective information on work, marital, and fertility histories up to age 50, and data on gender and other relevant sociodemographics.

\section{Measures}

\section{Later-life labour market biographies}

Our study takes a novel approach to modelling later-life labour market involvement-maintaining the integrity of individuals' long-term sequences and classifying them using dynamic Hamming distances (Lesnard, 2010) to make analysis feasible. The Analysis section provides details on the construction of these employment biographies. The resulting variable comprises seven trajectory 'types' summarising patterns over ages 50-69: 1 = Full-time throughout; 2 = Full-time, exit around 65 (reference); 3 = Full-time, exit around 60; 4 = Full-time, exit around 55; $5=$ Non-employed throughout; $6=$ Parttime dominant; and $7=$ Other (table 2). Note that, because we match each individual to their closest model biography, groups are not internally homogeneous; hence, the table and variable labels describe categories as comprising those who were mostly employed full-time, part-time or not at all, and/or who exited around age 65, age 60, etc.

Gender distinguishes women (yes $=1 ;$ no $=0$ ) from men.

Mid-life and prior family experiences comprise two parental measures-dependent children at age 50 (yes $=1 ;$ no $=0$ ) and age became a parent (in years)and two marital measures-married at age 50 (yes = 1 ; no $=0$ ) and marital ending by age 49 (yes $=1$; no = 0 ). In each case, one measure represents mid-life (age 50) circumstances and one captures prior history. Both marital measures are constructed from the starts and ends of current and prior marriages. Dependent children are those under age 19. Age at the birth of the first child is conditionally-coded (Ross \& Mirowsky, 1992: 223-224) to permit the retention of non-parents. As such, the measure is centered on its country-specific sample mean and entered into models in conjunction with a dummy for parent (yes = 1 ; no $=0$ ). Thus, individuals without children form the reference group, and those with children differ from them by an average amount (the coefficient for parent) plus an amount based on the age at which they entered parenthood (the coefficient for age became a parent). 


\section{Table 2. Description of the seven later-life labour market trajectories}

\begin{tabular}{ll} 
Later-life labour market trajectory & Employment pattern age 50-69 \\
\hline 1. Full-time throughout & $\begin{array}{l}\text { Mostly employed full-time ages 50-69 } \\
\text { Mostly employed full-time to approximately age } \\
\text { 2. Full-time, exit } 65\end{array}$ \\
$\begin{array}{l}\text { Mostly employed full-time to approximately age } \\
\text { 3. Full-time, exit } 60\end{array}$ & $\begin{array}{l}\text { M9, exit approximately age } 60 \\
\text { Mostly employed full-time to approximately age }\end{array}$ \\
4. Full-time, exit 55 & $\begin{array}{l}\text { 54, exit approximately age 55 } \\
\text { Mostly non-employed ages 50-69 }\end{array}$ \\
5. Non-employed throughout & $\begin{array}{l}\text { Mostly employed part-time with exits at various } \\
\text { ages, or 'downshifting' from full- to part-time }\end{array}$ \\
6. Part-time dominant & Erratic or unclassified pattern
\end{tabular}

Prior employment uses starts and ends for employment periods to code total years employed over ages 15-49. Distributions are equivalised by cutting at the values nearest each within-country quintile threshold, to produce a five-category ordinal variable.

Controls consist of three variables likely to be associated with gender, family experiences, and labour market involvement: education (low $=1$, medium $=2$, high (reference) $=3$ ); self-rated health at age 50 ( 1 = excellent, 2 = very good; 3 = good; 4 = fair; $5=$ poor), treated as ordinal in the models; and, for the US, 'minority' status (black/Hispanic $=1$; nonHispanic white $=0$ ).

Table 3 gives weighted means and percentages, by gender and country, for family experiences and prior employment. Of note are the comparatively large proportion of Italians (especially men) with dependent children and/or no marital ending at/by midlife, and the large share of Americans with a marital ending by midlife. These observations are broadly consistent with OECD data for the decades when our samples were under 50, which show low/non-existent divorce rates in Italy, comparatively high rates in the US, and relatively late mean ages at childbirth among Italian women (presumably even later for Italian men, given the gender age gap at first birth) (OECD, 2015a). In addition, while women in all four nations worked less than men in the years before age 50, the size of the gap ranged from less than six years for Sweden, through nearly ten for the US and a little more than 11 for Germany, to 17 for Italy. The relative magnitude of these gaps is in line with population-level data on men's and women's primeage labour force participation during the years relevant to our cohort (OECD, 2015b). 
Table 3. Weighted means and percentages for family and employment history measures, by gender and country ${ }^{\mathrm{a}}$

\begin{tabular}{|c|c|c|c|c|}
\hline & Germany & Italy & Sweden & $\begin{array}{l}\text { United } \\
\text { States }\end{array}$ \\
\hline Married at age $50(\%)$ & 87.1 & 88.4 & 81.0 & 78.2 \\
\hline Women & 87.6 & 87.3 & 78.5 & 75.5 \\
\hline Men & 86.6 & 89.8 & 83.9 & 81.1 \\
\hline Dependent child(ren) at age 50 (\%) & 40.2 & 53.1 & 43.2 & 39.0 \\
\hline Women & 32.8 & 45.4 & 33.9 & 33.2 \\
\hline Men & 48.8 & 62.4 & 53.5 & 45.2 \\
\hline Ever had a child (\%) & 91.4 & 89.0 & 87.7 & 82.1 \\
\hline Women & 93.6 & 90.0 & 87.9 & 85.9 \\
\hline Men & 88.9 & 87.7 & 87.5 & 77.9 \\
\hline Age in years at first child (if parent, ) & 26.4 & 27.2 & 25.9 & 24.5 \\
\hline Women & 24.7 & 25.6 & 24.7 & 22.8 \\
\hline Men & 28.6 & 29.1 & 27.2 & 26.4 \\
\hline Ever had a marriage end by age 49 (\%) & 12.8 & 7.0 & 20.8 & 34.5 \\
\hline Women & 13.8 & 9.0 & 21.7 & 36.5 \\
\hline Men & 11.6 & 4.5 & 19.8 & 32.4 \\
\hline Years employed ages 15-49 & 23.6 & 21.6 & 27.4 & 24.0 \\
\hline Women & 18.2 & 13.9 & 24.8 & 19.3 \\
\hline Men & 29.9 & 30.8 & 30.3 & 29.0 \\
\hline
\end{tabular}

${ }^{a}$ Weighted using the population/design/attrition weights supplied with the surveys.

\section{Analysis}

\section{Creating and grouping labour market sequences}

To construct the late-life labour market biographies, we first coded, for each of 20 time points (ages 50-69), a set of categorical variables representing whether the respondent was primarily employed full-time, part-time, or not at all. These 20 age-specific variables constitute the later-life labour market sequences. To make analysis feasible while also retaining the integrity of these biographies, we then grouped them using dynamic Hamming distances. Dynamic Hamming distances quantify how alike or distinct individual biographies are, one from another (Abbott and Tsay, 2000), by measuring the 'cost' of converting one person's sequence to another's (Maclndoe and Abbott, 2004). Sequences can then be grouped on that basis. We initially calculated distances relative to a set of 12 model biographies, constructed using existing knowledge of work and retirement among older adults. Because numbers were too small to support further analysis for some groups in the SHARE samples, we subsequently combined the seven biographies involving stretches of part-time work (leaving the remaining five as they were), to create a six-category measure for all countries. We then generated a seventh group by pulling, from the original 12 , those cases deemed a less than ideal match to any reference sequence, based on their distance from the one to which they were closest. Initial model sequences were developed separately by all authors, and later inspected for overlap (found to be substantial) and unique patterns of theoretical interest.

The validity of the 12-group classification was checked by examining between-group heterogeneity 
and within-group homogeneity - both considerable - using information on individuals' 'own-group' distance measures (available on request). In addition, group-specific sample means for employment states at each age (appendix 1) demonstrate that the collapsed typology represents identifiable longerterm patterns in later-life labour market involvement. Finally, further dynamic Hamming analyses using model reference sequences derived from detailed inspection of the seventh group (not shown) verified that no additional viable later-life employment biography groups could be extracted. Notwithstanding all of the above precautions, it is wise to keep in mind that the later-life labour market categories are not internally homogeneous, but rather, are clusters of individuals with similar employment sequences.

\section{Statistical analyses}

After assessing the gendering of older adults' labour market trajectories at baseline, we use nested multinomial regression models to investigate the roles of family experiences and prior employment in shaping observed patterns. The models first include controls (education, health at age 50 , and, for the US, minority status), then add family circumstances at age 50 (whether married and whether dependent children), followed by family history (whether a parent, age at first child, and whether any marital ending by age 49), and finally include prior employment (years employed ages 15-49). All analyses are stratified by gender and country to allow for expected gender- and country-specific effects of at least the family variables. All models are run in Stata, with procedures designed to handle multiple imputations. Estimates are weighted using the population/design/attrition weights supplied with the surveys.

As multinomial coefficients are difficult to interpret in their raw form - and because we run separate models for women and men - we evaluate the roles of family experiences and prior employment by converting the logits to adjusted probabilities (with confidence intervals) for each trajectory group, by gender and country. Probabilities are assessed at the country-specific sample means for all covariates, and confidence intervals are calculated using Rubin's rules (Rubin, 1987) to accommodate the uncertainty associated with multiple imputations. We then quantify the gendering of later-life labour market biographies using 'gender gradients' or relative risks (adjusted probability among women / adjusted probability among men) for each trajectory type, by country. Where male and female confidence intervals do not overlap, we compare the magnitudes of these gradients within and between countries, and across models.

\section{Imputation}

Our method requires complete data on the sequence variables. When data were missing, we imputed values to retain as many cases as possible and minimise bias. Imputation used a two-fold fully conditional multiple imputation specification (Van Buuren, Brand, Groothuis-Oudshoorn, \& Rubin, 2006) implemented in Stata -ice-. Two-fold ice was designed specifically for panel data, to impute using all crosssectional data plus prior and subsequent values for variables with missingness. In brief, the method computes, for each missing value, its posterior distribution conditional on other variables in an imputation model. A value is then sampled from this distribution under the assumption that missingness is random given the values of the other variables in the model. The method uses a Markov chain Monte Carlo algorithm. After double iteration of the algorithm, a complete dataset is created, consisting of a mix of imputed and known values. Enough complete datasets are generated -20 , in our case - to ensure the accuracy of substantive model estimates (Graham, Olchowski, \& Gilreath, 2007). All analyses are based on the simultaneous investigation of these 20 data sets, averaging over them and deriving standard errors according to Rubin's rules (Rubin 1987). Following optimal matching, missing covariate values were imputed using chained equations (White, Royston, \& Wood, 2011) in Stata -mi impute-. 


\section{Results}

\section{Baseline distributions and gradients}

Table 4. Weighted male and female percentages (Cls) in each later-life labour market trajectory type, along with gender gradients, by country

\begin{tabular}{|c|c|c|c|c|c|c|}
\hline \multirow[b]{2}{*}{$\begin{array}{l}\text { Later-life labour market } \\
\text { trajectory }\end{array}$} & \multicolumn{3}{|c|}{ Germany } & \multicolumn{3}{|c|}{ Italy } \\
\hline & Men & Women & $\begin{array}{c}\text { Female / } \\
\text { Male } \\
\text { Gradient }^{\mathrm{a}}\end{array}$ & Men & Women & $\begin{array}{c}\text { Female / } \\
\text { Male } \\
\text { Gradient }^{\mathrm{a}}\end{array}$ \\
\hline \multirow{2}{*}{ Total } & 100.0 & 100.0 & & 100.0 & 100.0 & \\
\hline & (sample $\mathrm{N}=252$ ) & (sample $\mathrm{N}=223$ ) & & (sample $\mathrm{N}=473$ ) & (sample $\mathrm{N}=462$ ) & \\
\hline 1 Full-Time Throughout & $5.2(2.3,8.2)$ & $1.5(-0.6,3.7)$ & 0.29 & $9.9(6.3,13.5)$ & $2.7(0.8,4.6)$ & 0.28 \\
\hline 2 Full-Time, Exit 65 & $39.6(33.1,46.0)$ & $7.5(3.1,11.9)$ & 0.19 & $14.5(11.2,17.8)$ & $3.7(1.8,5.7)$ & 0.26 \\
\hline 3 Full-Time, Exit 60 & $34.5(28.2,40.8)$ & $12.5(7.2,17.8)$ & 0.36 & $32.5(27.7,37.3)$ & $10.6(7.3,13.9)$ & 0.33 \\
\hline 4 Full-Time, Exit 55 & $12.3(7.7,17.0)$ & $4.0(1.4,6.6)$ & 0.33 & $23.7(19.1,28.4)$ & $9.4(6.4,12.4)$ & 0.40 \\
\hline 5 Non-Employed Throughout & $2.5(-0.1,5.0)$ & $47.8(40.5,55.0)$ & 19.26 & $10.6(7.5,13.8)$ & $65.7(60.7,70.7)$ & 6.18 \\
\hline 6 Part-time Dominant & $2.9(0.3,5.4)$ & $21.2(15.5,26.8)$ & 7.38 & $3.9(1.1,6.8)$ & $5.5(3.3,7.8)$ & 1.41 \\
\hline \multirow[b]{2}{*}{$\begin{array}{l}\text { Later-life labour market } \\
\text { trajectory }\end{array}$} & & Sweden & & \multicolumn{3}{|c|}{ United States } \\
\hline & Men & Women & $\begin{array}{c}\text { Female / } \\
\text { Male } \\
\text { Gradient }^{\mathrm{a}}\end{array}$ & Men & Women & $\begin{array}{c}\text { Female / } \\
\text { Male } \\
\text { Gradient }^{\mathrm{a}}\end{array}$ \\
\hline Total & $\begin{array}{r}100.0 \\
\text { (sample } \mathrm{N}=316 \text { ) }\end{array}$ & $\begin{array}{r}100.0 \\
\text { (sample } \mathrm{N}=338 \text { ) }\end{array}$ & & $\begin{array}{r}100.0 \\
\text { (sample } \\
\mathrm{N}=4,201 \text { ) }\end{array}$ & $\begin{array}{r}100.0 \\
\text { (sample } \\
N=4,631 \text { ) }\end{array}$ & \\
\hline 1 Full-Time Throughout & $14.2(10.0,18.4)$ & $5.2(2.7,7.7)$ & 0.37 & $18.6(17.0,20.1)$ & $9.6(8.6,10.6)$ & $0.52+$ \\
\hline 2 Full-Time, Exit 65 & $46.2(40.3,50.2)$ & $29.5(24.3,34.8)$ & $0.64 \dagger$ & $21.4(19.9,22.8)$ & $13.7(12.6,14.8)$ & $0.64 \dagger$ \\
\hline 3 Full-Time, Exit 60 & $24.3(19.2,29.4)$ & $18.3(13.7,22.9)$ & 0.75 & $19.2(17.8,20.6)$ & $13.7(12.6,14.8)$ & $0.71+$ \\
\hline 4 Full-Time, Exit 55 & $5.1(2.3,7.8)$ & $5.8(2.9,8.8)$ & 1.16 & $8.2(7.3,9.2)$ & $9.8(8.8,10.8)$ & 1.19 \\
\hline 5 Non-Employed Throughout & $1.2(-0.3,2.6)$ & $6.6(3.9,9.4)$ & 5.64 & $7.3(6.4,8.1)$ & $19.9(18.7,21.2)$ & 2.75 \\
\hline 6 Part-time Dominant & $5.7(2.9,8.5)$ & $26.4(21.3,31.5)$ & 4.66 & $20.3(18.9,21.7)$ & $24.1(22.7,25.6)$ & $1.19+$ \\
\hline
\end{tabular}

${ }^{\text {a }}$ Gradients are the ratio of the female proportion to the male proportion. As such, they measure the extent to which one gender predominates in a given trajectory group in a given country. Light grey shading identifies larger gradients $>2.0$ for female-dominated or $<0.5$ for male-dominated trajectories), for which male and female confidence intervals do not overlap; dark grey shading identifies very large gradients $(>5.0$ or $<0.2)$.

+ Confidence intervals do not overlap for male and female estimates, but gradients are smaller than two times. Confidence intervals tend not to overlap for the American sample, simply because of the much larger $\mathrm{N}$; hence, we focus on the magnitudes of (significant) gaps.

Table 4 displays weighted baseline percentages for each trajectory group, by gender and country, along with the resulting gender gradients (female percentage / male percentage). Light grey shading identifies larger gradients $(>2.0$ for femaledominated trajectories or $<0.5$ for maledominated)-and dark grey pinpoints very large gradients (> 5.0 or $<0.2$ ) -in which gender-specific confidence intervals do not overlap. Note that we focus on the magnitudes of (significant) gaps as confidence intervals tend not to overlap for the American sample even when gradients are fairly small, simply because of the much larger $\mathrm{N}$. We highlight two features: the amount and type of gendering; and how this varies between countries. We leave aside discussion of the residual category, as its meaning is not consistent across genders or countries - although all models do include this group.

Most trajectory types are gendered, with gradients generally supporting Hypothesis 1: Men predominate in the 'attached' biographies (1-3) and women in the less 'attached' (5 and 6). Interestingly, though, gradients are typically largest for female-dominated trajectories. For example, continual non-employment in Germany is almost entirely female; and the part- 
time dominant path in Germany, as well as continual non-employment in Italy and Sweden, all have gradients larger than five. Only one male-dominated biography has a gradient of more than five times (i.e., less than 0.20): full-time to exit around 65 in Germany.

The shading in table 4 provides clear support for Hypothesis 2: The gendering of later-life employment biographies is strongest in Germany and Italy, where only the very small groups display non-significant male-female differences. Unexpectedly, however, gradients are often larger for Germany than for Italy, despite the gender gap in state pension ages in the latter country. Proportions underlying the strongest gradients show that a far smaller share of German than Italian men followed the female-dominated continual non-employment path, and a far greater proportion of German men are in the maledominated full-time to exit around 65 group.

Beyond this, the results add nuance to the notion that male-female differences will be weakest in
Sweden and the US (Hypothesis 2). Instead, gendering is intermediate for Sweden, where one maledominated and two female-dominated trajectories have steep gradients, and weakest for the US, where only continual non-employment is clearly gendered. Of note is the part-time dominant biography among Swedes, which is both strongly feminized and large (26\% of women). This implies that the Swedish dualearner strategy of incorporating mothers into the labour force partly via better-quality short-hour jobs carries through to older ages. Subsequent investigation (not shown) reveals that Swedish women in the part-time dominant group had spent, on average, nearly a third of their younger years working 'short' hours, versus about a tenth of those years for all other Swedish women combined. Despite this evidence of gendering, we note that the (always male-dominated) full-time to exit around 65 path is actually the most common one taken by Swedish women; and this cannot be said of any other country. 


\section{Family and prior work}

Table 5. Female/male gender gradients ${ }^{a}$ for later-life labour market trajectories, by country

\begin{tabular}{ccccc} 
Model 1 & Model 2 & Model 3 & Model 4 \\
(controls & $\begin{array}{c}\text { (+ family } \\
\text { only) }\end{array}$ & $\begin{array}{c}\text { age 50) } \\
\text { (+ family }\end{array}$ & $\begin{array}{c}\text { history) } \\
\text { (+ work }\end{array}$ & history) \\
\hline
\end{tabular}

1. Full-time throughout ${ }^{b}$

2. Full-time, exit $65 / 65+$

Germany

3. Full-time, exit 60

$\begin{array}{llll}0.13 & 0.12 & 0.13 & 0.19 \\ 0.31 & 0.29 & 0.29 & 0.68 \\ 0.32 & 0.35 & 0.24 & 0.89\end{array}$

4. Full-time, exit 55

5. Non-employed throughout

6. Part-time dominant

$\begin{array}{cccc}\dagger & \dagger & \dagger & \dagger \\ 83.42^{c} & 149.20^{c} & 204.63^{c} & 270.84^{c}\end{array}$

1. Full-time throughout

2. Full-time, exit 65

0.19

Italy

3. Full-time, exit 60

0.19

0.07

0.03

0.04

4. Full-time, exit 55

0.31

0.19

0.21

0.35

5. Non-employed throughout

0.41

0.29

0.30

0.47

6. Part-time dominant

6.53

0.38

0.15

0.31

1.37

6.62

6.76

3.04

1. Full-time throughout

2. Full-time, exit 65

3. Full-time, exit 60

4. Full-time, exit 55

5. Non-employed throughout

6. Part-time dominant

1. Full-time throughout

2. Full-time, exit 65

3. Full-time, exit 60

4. Full-time, exit 55

5. Non-employed throughout

6. Part-time dominant

\begin{tabular}{llll}
\multicolumn{5}{c}{ Sweden } \\
0.31 & 0.33 & 0.07 & 0.07 \\
0.60 & 0.59 & 0.59 & 0.69 \\
0.73 & 0.67 & 0.74 & 0.78 \\
0.95 & 0.98 & 0.98 & 1.07 \\
$\dagger$ & $\dagger$ & $\dagger$ & $\dagger$ \\
5.10 & 8.13 & 8.56 & 7.70 \\
\hline \multicolumn{5}{c}{ United States } \\
0.49 & 0.49 & 0.50 & 0.57 \\
0.64 & 0.63 & 0.63 & 0.68 \\
0.72 & 0.71 & 0.73 & 0.80 \\
1.26 & 1.23 & 1.24 & 1.23 \\
2.94 & 3.03 & 3.15 & 1.91 \\
1.27 & 1.29 & 1.27 & 1.40 \\
\hline
\end{tabular}

\footnotetext{
${ }^{a}$ In the calculation of the underlying adjusted probabilities, all covariates are set to their within-country sample means. Gradients are highlighted where confidence intervals for male and female adjusted proportions do not overlap. Light grey = male-dominated, dark grey = female-dominated.

${ }^{\mathrm{b}}$ Trajectories 1 and 2 were combined for Germany only.

'The very large gradients (relative to Table 4) occur because low education dramatically decreases men's, but not women's, odds of having this trajectory. This is largely a function of small cells: There are few German men in in the part-time dominant group and, as a result, the cell for low education is actually empty.

tVirtually all cases are female.
} 
We next investigate the contributions of family experiences and prior employment to the above patterns (table 5). Again, we quantify male-female distinctions using gender gradients. But here the underlying probabilities are calculated from regression coefficients that adjust for the influence of family and earlier work. (See Appendix 2 for the adjusted probabilities and confidence intervals, and Appendix 3 for average marginal covariate effects.) In this table, light-grey shading indicates maledominated, and dark-grey, female-dominated trajectories. Again, we do not discuss the residual category - although all models do include this group. In addition, for German men we combine full-time to exit around 65 and full-time throughout, to correspond to women's trajectories in that country, where collapsing was necessary because so few were in ongoing full-time employment. For similar reasons, we fold the small number of German and Swedish men in continual non-employment into the residual category. Model 1, which adjusts for controls only, is included as the comparator for Model 2. Models 2 and 3 test Hypothesis $3 a-$ that gender differences in later-life labour market biographies are rooted partly in the differential impact of family experiences over the life course. Model 4 tests the hypothesis that the gendering of later-life labour market involvement is at least partly due to differential attachment to the labour force at younger ages (Hypothesis 4a). We highlight two features of table 5: how gradients shift with the addition of explanatory variables; and crossnational differences in those shifts.

Relative to the model with controls, some model 2 gender gaps increase - most obviously for the parttime dominant path among Germans and Swedes and ongoing full-time employment among Italians. (For gradients < 1, a larger gap is represented by a decrease from one model to the next, meaning a greater preponderance of men.) In addition, women's greater probability of continual non-employment increases for Germany and Sweden, although no gradient is shown because no male comparison group exists. Model 3 (table 5) displays the additional influence of family experiences earlier in the life course. Gender differentials increase for the parttime dominant path among Germans, ongoing full- time employment among Swedes, and the full-time to exit around 55 biography among Italians.

Models 2 and 3 provide support for the notion that the gendering of later-life labour market involvement arises, in part, from the gender-specific influences of family experiences over the life course (Hypothesis $3 a$ ). They only partially back Hypothesis $3 b-$ that effects will be stronger for Germany and Italy than for Sweden and the US. Instead, family experiences appear more important in all three European countries (two breadwinner-caregiver and one dualearner) than in the US (dual-earner), where they have little or no impact.

Model 4 (table 5) tests Hypothesis $4 a$ - that the gendering of older adults' labour market trajectories arises at least partly from gendered earlier attachment to the labour force. Indeed, prior employment partially explains many of the familyadjusted gender gaps (trajectories 2 and 5 in Germany; trajectory 6 and, to some extent, trajectory 2 in Sweden; trajectories 3-5 in Italy; and trajectory 5 in the US), or reduces them to non-significance (trajectory 2 in Italy; trajectory 3 in Germany and the US). The results are also consistent with Hypothesis $4 b$ : Male-female differences in earlier employment account for a greater share of the gendering of laterlife labour market involvement in Germany and Italy, where most trajectory types are affected, than in Sweden and the US, where effects primarily involve one male-dominated and one female-dominated biography.

\section{Discussion}

This study adopted a comparative gendered life course approach, to extend knowledge of older adults' labour market involvement. While the majority of previous work has focused on retirement and thereby underrepresented women, our analysis drew on extended biographical sequences and fully incorporated both genders in four nations with diverse approaches to family and paid work over the life course. This strategy - to our knowledge, unique among studies of older adults' labour market involvement-generated results that both confirmed and expanded existing knowledge.

Consistent with expectations, in every nation women prevailed in groups representing a weak(er) 
attachment to the labour market in later life and men in those signifying a strong(er) attachment. Additionally, this pattern was especially pronounced for Germany and Italy, where policies have generally supported men's, but not women's, paid work earlier in the life course. These findings are in line with crosssectional estimates of older adults' labour force participation (OECD, 2011). However, they also offer novel insights into how gender and institutional contexts play out with respect to long-term patterns of labour market involvement. For example, across all nations, gradients tended to be stronger for femalethan male-dominated biographies, implying that women were more likely to follow 'male' paths than the reverse. Future research should investigate the institutional and cultural factors behind this finding (e.g., the extent of support for men's family work), along with its relevance to upcoming cohorts where family roles may be less gendered.

We also found support for the idea that malefemale differences in later-life labour market involvement arise, in part, from the gendered influence of family experiences over the life course. More importantly, we offered new evidence that family ties matter more in the corporatist and southern welfare regimes, where a breadwinnercaregiver division of labour structures the adult life course, than they do in the liberal nation, where a dual-earner model is (passively) promoted. This highlights the need for approaches to older adults' labour market involvement that consider not only state benefits that 'pull,' and workplace barriers that 'push,' older adults out of the labour force, but also policies related to family circumstances throughout the life course. Future studies might extend these findings by drawing on more detailed marital and parental histories and identifying the specific social, cultural, and policy mechanisms by which they operate in various institutional contexts.

The real significance of family policies undoubtedly lies in their impact on the gendering of earlier attachment to the labour force, which may carry through to older ages. Indeed, prior employment accounted for a significant share of male-female distinctions in later-life labour market involvement. Again, this was most apparent for Germany and Italy, where, historically, women have been encouraged to leave the labour force once married and/or raising children. Conversely, work histories explained less of the gendering at older ages in Sweden, where the state has, for several decades, actively supported women's employment throughout the life course, and in the US, where the state has passively promoted dual-earning. These findings reiterate the need for approaches to older adults' employment that consider the entire life course.

Three key results were not anticipated. First, in some ways the divide was between the three European countries and the US, rather than between those adhering to a breadwinner-caregiver and a dual-earner family model. Family experiences made almost no difference to the gendering of older Americans' labour market biographies. But the parttime dominant biography among Swedes was both highly gendered (female) and common; and the effects of family experiences were particularly strong for that group. These findings, along with the disproportionate levels of earlier part-time work found for Swedish women in the part-time dominant group, suggest that that nation's strategy of incorporating mothers into the labour force partly by means of better-quality short-hour jobs carries through to older ages.

Second, we turned up particularly strong evidence of gendering for Germany - stronger than that found for the other breadwinner-caregiver nation (Italy) and despite the gender gap in the latter nation's pension ages. The much smaller share of German than Italian men in the female-dominated continual nonemployment group may follow from Italy's relatively lenient access to illness/disability pensions for older workers; and the far greater proportion of German men with the male-dominated full-time to exit around 65 biography may reflect Germany's pension system, which is closely tied to (male) earnings over the life course (Buchholz et al., 2006).

And finally, the results for work histories were somewhat surprising. We found roughly similar effects for the US and Sweden, as expected; but this was despite the larger gender gap in prior employment in the US, which, all else equal, should have meant that work histories accounted for more gendering of later-life labour market involvement in that country. That they did not implies that some American women with a weak(er) prior attachment to the labour force ended up behaving more like men 
with respect to their labour market involvement in older adulthood. This may reflect contextual factors - a heavy reliance on accumulated personal resources to fund retirement - requiring some without steady employment records to increase their work effort as they approach (or pass) state pension age. Pending the availability of more detailed data, future research should further investigate crossnational differences in the role of work histories (including full-time/part-time status and interactions with family histories) in shaping older women's employment biographies.

Our contributions should be viewed in light of several limitations. One is the necessary sacrifice of some precision in the construction of the later-life labour market groups. We clustered individuals whose trajectories are similar but not identical, and we cannot say whether this 'muddied' associations with the key explanatory variables. This constraint is, however, inseparable from one of the study's strengths: the ability to include women, even those without steady (or any) employment in their later years, and thus to assess gender differences in older adults' employment trajectories across a range of welfare states. A second consideration is that imputations introduced some uncertainty into the labour market sequences. While this is of concern, we minimised its impact - using a two-fold fully conditional specification, running a large number of imputations, and appropriately adjusting standard errors. Moreover, the vast majority of sequences were complete for all countries except the US, and our sensitivity analysis using a reduced US sample did not alter our major conclusions. A third limitation is the possibility that our measures of family experiences did not capture all relevant aspects, while our prior employment variable could not incorporate, for example, part-time work. These shortcomings reflect a combination of data and methodological constraints-inconsistent information on prior work periods in the HRS, and relatively small sample sizes for the SHARE countries, which restricted the number and type of covariates possible.

Our discussion highlights at least three policy implications. First is the need to go beyond a focus on workplace and economic factors that shape employment decisions in the years surrounding public pension eligibility. We found evidence that older adults' labour market trajectories are influenced by policies related not only to paid work but also to caregiving, and by those affecting not only immediate decisions but also choices made earlier in the life course. Second are possible vulnerabilities associated with the drive to extend working life. The feminization of non-employment in Germany and Italy, and of part-time work in Germany and Sweden, may leave women out in the cold if policies fail to consider the gendering of paid work and caregiving earlier in the life course. Third, the American case hints at concerns related to weakly regulated labour markets and scanty public provisions. That women with weak(er) work histories may end up behaving more like men with respect to later-life labour market involvement, raises questions about the quality of at least some older Americans' work - questions whose urgency will increase if adults are required to work longer. These considerations should be a central focus of ongoing cross-national investigations of older adults' labour market trajectories.

\section{Acknowledgements}

This research was funded by the Canadian Institutes of Health Research [grant number MOP 11952, Peggy McDonough PI] and the Social Sciences and Humanities Research Council [grant number 435121267, Peggy McDonough PI]. Anne McMunn was supported by the European Research Council [Starting Grant number ERC2011-StG_20101124, Anne McMunn PI]; Amanda Sacker by the UK Economic and Social Research Council [grant number ES/J019119/1, Amanda Sacker PI]; and Laurie Corna by the Economic and Social Research Council/Medical Research Council [grant number ES/L002825/1, Karen Glaser PI].

The HRS is sponsored by the National Institute on Aging [grant number NIA U01AG009740] and is conducted by the University of Michigan. We also made occasional use of the RAND HRS Data file, a simplified longitudinal dataset based on the HRS and developed at RAND with funding from the National Institute on Aging and the 
Social Security Administration. The SHARE is primarily funded by the European Commission through FP5 [QLK6CT-2001-00360], FP6 [SHARE-I3: RII-CT-2006-062193, COMPARE: CIT5-CT-2005-028857, SHARELIFE: CIT4-CT2006-028812] and FP7 [SHARE-PREP: N²11909, SHARE-LEAP: N²27822, SHARE M4: $N^{\circ} 261982$ ]. Additional funding comes from the German Ministry of Education and Research, the U.S. National Institute on Aging [U01_AG09740-13S2, P01_AG005842, P01_AG08291, P30_AG12815, R21_AG025169, Y1-AG-4553-01, IAG_BSR06-11, OGHA_04-064], and funding sources specific to each national dataset (see http://www.shareproject.org/contact-organisation/funding.html).

\section{References}

Abbott, A., \& Tsay, A. (2000). Sequence Analysis and Optimal Matching Methods in Sociology. Sociological Methods \& Research, 29(1), 3-33. http://dx.doi.org/10.1177/0049124100029001001

Alley, D. E., Putney, N. M., Rice, M., \& Bengtson, V. L. (2010). The Increasing Use of Theory in Social Gerontology: 1990-2004. Journals of Gerontology Series B-Psychological Sciences and Social, 65(5), 583-590. http://dx.doi.org/10.1093/geronb/gbq053

Beckstette, W., Lucchini, M., \& Schizzerotto, A. (2006). Men's Late Careers and Career Exits in Italy. In H.P.Blossfeld, S. Buchholz, \& D. Hofäcker (Eds.), Globalization, Uncertainty, and Late Careers in Society (pp. 100-118). New York: Routledge.

Biesanz, J. C., Deeb-Sossa, N., Papadakis, A. A., Bollen, K. A., \& Curran, P. J. (2004). The role of coding time in estimating and interpreting growth curve models. Psychological methods, 9(1), 30-52. http://dx.doi.org/10.1037/1082-989X.9.1.30

Billari, F. C., \& Piccarreta, R. (2005). Analysing demographic life courses through sequence analysis. Mathematical Population Studies 12, 81-106. http://dx.doi.org/10.1080/08898480590932287

Blossfeld, H.-P., \& Drobnič, S. (2001). A Cross-National Comparative Approach to Couples' Careers. Oxford: Oxford University Press.

Blossfeld, H.-P., Buchholz, S., \& Hofäcker, D. (2006). Globalization, Uncertainty and Late Careers in Society. New York: Taylor \& Francis. http://dx.doi.org/10.4337/9781781007495

Blossfeld, H.-P., Buchholz, S., \& Kurz, K. (Eds.). (2011). Aging Populations, Globalization and the Labor Market: Comparing Late Working Life and Retirement in Modern Societies. Cheltenham ; Northampton, MA: Edward Elgar Pub. http://dx.doi.org/10.4337/9781849805858

Börsch-Supan, A. \& Jürges, H. (Eds.). (2005). The Survey of Health, Ageing, and Retirement in Europe Methodology. Munich: Mannheim Research Institute for the Economics of Ageing. Retrieved from http://www.shareproject.org/uploads/tx_sharepublications/SHARE_BOOK_METHODOLOGY_Wave1.pdf

Börsch-Supan, A., Hank, K., Jürges, H., \& Schröder, M. (2009). Introduction: empirical research on health, ageing and retirement in Europe. Journal of European Social Policy, 19(4), 293-300. http://dx.doi.org/10.1177/1350506809341510

Bowlby, G. (2007). Defining Retirement. Perspectives, 8(2), 15-9.

Buchholz, S., \& Hofäcker, D., \& Blossfeld, H.-P. (2006). Globalization, accelerating economic change and late careers. In H.-P. Blossfeld, S. Buchholz, \& D. Hofäcker (Eds.), Globalization, Uncertainty and Late Careers in Society (pp. 1-24). New York: Taylor \& Francis.

Cooke, M. (2006). Policy Changes and the Labour Force Participation of Older Workers: Evidence from Six Countries. Canadian Journal on Aging/La Revue Canadienne Du Vieillissement, 25(04), 387-400. http://dx.doi.org/10.1353/cja.2007.0015

Denaeghel, K., Mortelmans, D., \& Borghgraef, A. (2011). Spousal influence on the retirement decisions of singleearner and dual-earner couples. Advances in Life Course Research, 16(3), 112-123. http://dx.doi.org/10.1016/j.alcr.2011.06.001 
Dentinger, E., \& Clarkberg, M. (2002). Informal Caregiving and Retirement Timing among Men and Women: Gender and Caregiving Relationships in Late Midlife. Journal of Family Issues, 23(7), 857-879. http://dx.doi.org/10.1177/019251302236598

Drobnic, S., Blossfeld, H. P., \& Rohwer, G. (1999). Dynamics of women's employment patterns over the family life course: A comparison of the United States and Germany. Journal of Marriage and the Family, 61(1), 133-146. http://dx.doi.org/10.2307/353889

Duval, R. (2003). The Retirement Effects of Old-Age Pension and Early Retirement Schemes in OECD Countries. OECD Publishing. Retrieved from https://ideas.repec.org/p/oec/ecoaaa/370-en.html

Esping-Andersen, G. (1990). The three worlds of welfare capitalism. Princeton, N.J.: Princeton University Press.

Fasang, A. E. (2010). Retirement: Institutional Pathways and Individual Trajectories in Britain and Germany. Sociological Research Online, 15(2). http://dx.doi.org/10.5153/sro.2110

-----. (2012). Retirement Patterns and Income Inequality. Social Forces, 90(3), 685-711. http://dx.doi.org/10.1093/sf/sor015

Gal, J. (2010). Is there an Extended Family of Mediterranean Welfare States? Journal of European Social Policy, 20, 283-300. http://dx.doi.org/10.1177/0958928710374374

Gornick, J. C. and Meyers, M. K. (2006). Welfare Regimes in Relation to Paid Work and Care. Revue française des affaires sociales, 5(5), 167-88.

Graham, J., Olchowski, A., \& Gilreath, T. (2007). How Many Imputations are Really Needed? Some Practical Clarifications of Multiple Imputation Theory. Prevention Science, 8(3), 206-213. http://dx.doi.org/10.1007/s11121-007-0070-9

Halldén, K., Gallie, D., \& Zhou, Y. (2012). The skills and autonomy of female part-time work in Britain and Sweden. Research in Social Stratification and Mobility, 30(2), 187-201. http://dx.doi.org/10.1016/j.rssm.2011.07.001

Halpin, B. (2014). SADI: sequence analysis tools for Stata. Working Paper WP2014-03. University of Limerick Department of Sociology Working Paper Series. Limerick, Ireland: University of Limerick. Retrieved from http://www.ul.ie/sociology/wp2014-03.pdf

Han, S.-K., \& Moen, P. (1999a). Work and Family Over Time: A Life Course Approach. The ANNALS of the American Academy of Political and Social Science, 562(1), 98-110. http://dx.doi.org/10.1177/0002716299562001007

Han, S-K.., \& Moen, P. (1999b). Clocking Out: Temporal Patterning of Retirement. American Journal of Sociology, 105(1), 191-236. http://dx.doi.org/10.1086/210271

Hank, K. (2004). Effects of Early Life Family Events on Women's Late Life Labour Market Behaviour An Analysis of the Relationship between Childbearing and Retirement in Western Germany. European Sociological Review, 20(3), 189-198. http://dx.doi.org/10.1093/esr/jch017

Hank, K., \& Korbmacher, J. M. (2013). Parenthood and Retirement: Gender, cohort, and welfare regime differences. European Societies, 15(3), 446-461. http://dx.doi.org/10.1080/14616696.2012.750731 Heeringa, S. G., \& Connor, J. H. (1995). Technical Description of the Health and Retirement Survey Sample Design (Public Use Version). Ann Arbor, MI: Institute for Social Research. http://dx.doi.org/10.7826/ISR-UM.06.585031.001.05.0001.1995 Retrieved from http://hrsonline.isr.umich.edu/sitedocs/userg/HRSSAMP.pdf

Hofäcker, D., Stoilova, R., \& Riebling, J. R. (2013). The Gendered Division of Paid and Unpaid Work in Different Institutional Regimes: Comparing West Germany, East Germany and Bulgaria. European Sociological Review, 29(2), 192-209. http://dx.doi.org/10.1093/esr/jcr055

Kahn, L. (2010). Labor Market Policy: A Comparative View on the Costs and Benefits of Labor Market Flexibility (CESifo Working Paper Series No. 3140). CESifo Group Munich. Retrieved from https://ideas.repec.org/p/ces/ceswps/_3140.html 
Kail, B. L., \& Warner, D. F. (2013). Leaving Retirement: Age-Graded Relative Risks of Transitioning Back to Work or Dying. Population Research and Policy Review, 32(2), 159-182. http://dx.doi.org/10.1007/s11113-0129256-3

Katz, M. B. (2010). The American Welfare State and Social Contract in Hard Times. Journal of Policy History, 22(4), 508-529. http://dx.doi.org/10.1017/S0898030610000242

Korpi, W. (2000). Faces of Inequality: Gender, Class, and Patterns of Inequalities in Different Types of Welfare States. Social Politics: International Studies in Gender, State \& Society, 7(2), 127-91. http://dx.doi.org/10.1093/sp/7.2.127

Korpi, W., Ferrarini, T., \& Englund, S. (2013). Women's Opportunities under Different Family Policy Constellations: Gender, Class, and Inequality Trade-offs in Western Countries Re-examined. Social Politics: International Studies in Gender, State and Society, 20(1), 1-40. http://dx.doi.org/10.1093/sp/jxs028

Lesnard, L. (2010). Setting Cost in Optimal Matching to Uncover Contemporaneous Socio-Temporal Patterns. Sociological Methods \& Research, 38, 389-419. http://dx.doi.org/10.1177/0049124110362526

Lindquist, G. S. (2006). Late Careers and Career Exits in Sweden. In H.-P. Blossfeld, S. Buchholz, \& D. Hofäcker (Eds.), Globalization, Uncertainty, and Late Careers in Society (pp. 211-233). New York: Routledge.

MacIndoe, H., \& Abbott, A. (2004). Sequence Analysis and Optimal Matching Techniques for Social Science Data. In M. A. Hardy, \& A. Bryman (Eds.), Handbook of Data Analysis (pp. 387-405). London: Sage. http://dx.doi.org/10.4135/9781848608184.n17

Mayer, K. U. (2004). Whose Lives? How History, Societies, and Institutions Define and Shape Life Courses. Research in Human Development, 1(3), 161-87. http://dx.doi.org/10.1207/s15427617rhd0103_3

Moen, P. (1996). A life course perspective on retirement, gender, and well-being. Journal of Occupational Health Psychology, 1(2), 131-144. http://dx.doi.org/10.1037/1076-8998.1.2.131

Moen, P., \& Flood, S. (2013). Limited Engagements? Women's and Men's Work/Volunteer Time in the Encore Life Course Stage. Social Problems, 60(2), 206-233. http://dx.doi.org/10.1525/sp.2013.60.2.206

Morris, D., \& Mallier, T. (2003). Employment of Older People in the European Union. LABOUR, 17(4), 623-648.

OECD. (2005). Pensions at a Glance 2005. Paris: Organisation for Economic Co-operation and Development. http://dx.doi.org/10.1111/j.1121-7081.2003.00255.x Retrieved from http://www.oecdilibrary.org/finance-and-investment/oecd-pensions-at-a-glance-2005 pension_glance-2005-en

-----. (2006). Ageing and Employment: Live Longer, Work Longer. Paris: OECD Publishing. Retrieved from https://www.oecd.org/employment/livelongerworklonger.htm

-----. (2009). Employment Rate of Older Workers: Percent of Population Aged 55-64. http://dx.doi.org/10.1787/20752342-2009-table6 Retrieved from http://dx.doi.org/10.1787/207523422009-table6

-----. (2011). Pensions at a Glance 2011. Paris: Organisation for Economic Co-operation and Development. Retrieved from http://www.oecd-ilibrary.org/content/book/pension_glance-2011-en

-----. (2015a). OECD Family Database. Paris: Organisation for Economic Co-operation and Development. Retrieved from www.oecd.org/social/family/database.htm

-----. (2015b). OECD.Stat. Tables for "LFS by sex and age - indicators." Retrieved from http://stats.oecd.org/index.aspx

Ogg, J., \& Renaut, S. (2007). The influence of living arrangements, marital patterns and family configuration on employment rates among the 1945-1954 birth cohort: evidence from ten European countries. European Journal of Ageing , 4(3), 155-169. http://dx.doi.org/10.1007/s10433-007-0061-5

Persky, L. (2011). More than a Woman's Issue: The Making of Family Policy in the US and UK Since 1960 (SSRN Scholarly Paper No. ID 1901351). Rochester, NY: Social Science Research Network. Retrieved from http://papers.ssrn.com/abstract=1901351

Pienta, A. M. (1999). Early Childbearing Patterns and Women's Labor Force Behavior in Later Life. Journal of Women \& Aging, 11, 69-84. http://dx.doi.org/10.1300/J074v11n01_06 
Pienta, A. M., Burr, J. A., \& Mutchler, J. E. (1994). Women's Labour Force Participation in Later Life: The Effects of Earlier Work and Family Experiences. Journal of Gerontology, 49(5), S231-9. http://dx.doi.org/10.1093/geronj/49.5.S231

Pienta, A. M., \& Hayward, M. D. (2002). Who Expects to Continue Working After Age 62? The Retirement Plans of Couples. The Journals of Gerontology Series B: Psychological Sciences and Social Sciences, 57(4), S199S208. http://dx.doi.org/10.1093/geronb/57.4.S199

Pleau, R. L. (2010). Gender Differences in Postretirement Employment. Research on Aging, 32(3), 267 -303. http://dx.doi.org/10.1177/0164027509357706

Radl, J. (2013). Labour Market Exit and Social Stratification in Western Europe: The Effects of Social Class and Gender on the Timing of Retirement. European Sociological Review, 29(3), 654-668. http://dx.doi.org/10.1093/esr/jcs045

Ross, C. E., \& Mirowsky, J. (1992). Households, Employment, and the Sense of Control. Social Psychology Quarterly, 55(3), 217-235. http://dx.doi.org/10.2307/2786793

Rovny, A. E. (2011). Welfare state policy determinants of fertility level: A comparative analysis. Journal of European Social Policy, 21(4), 335-347. http://dx.doi.org/10.1177/0958928711412221

Rubin, D. B. (1987). Multiple Imputation for Non-response in Surveys. Chichester, England: Wiley. http://dx.doi.org/10.1002/9780470316696

Rydell, I. (2002). Demographic Patterns from the 1960s in France, Italy, Spain and Portugal (Arbetsrapport No. 2003:2). Institute for Futures Studies. Retrieved from https://ideas.repec.org/p/hhs/ifswps/2003_002.html

Siaroff, A. (1994). Work, Welfare and Gender Equality: A New Typology. In Sainsbury, D. (Ed.), Gendering Welfare States Gendering welfare states (pp. 82-100). London: SAGE. http://dx.doi.org/10.4135/9781446250518.n6

Sundström, E. (2003). Gender Regimes, Family Policies and Attitudes to Female Employment : A Comparison of Germany, Italy and Sweden. Doctoral Dissertation in Sociology, Faculty of Social Sciences, Umeå University. Retrieved from www.diva-portal.org/smash/get/diva2:142190/FULLTEXT01.pdf

Szinovacz, M. E., \& Deviney, S. (2000). Marital Characteristics and Retirement Decisions. Research on Aging, 22(5), 470-498. http://dx.doi.org/10.1177/0164027500225002

Szinovacz, M. E., DeViney, S., \& Davey, A. (2001). Influences of family obligations and relationships on retirement : Variations by gender, race, and marital status. The Journals of Gerontology. Series $B$, Psychological Sciences and Social Sciences, 56(1), S20-S27. http://dx.doi.org/10.1093/geronb/56.1.S20

Trifiletti, R. (1999). Southern European Welfare Regimes and the Worsening Position of Women. Journal of European Social Policy, 9(1), 49-64. http://dx.doi.org/10.1177/095892879900900103

UNESCO. (2006). International Standard Classification of Education ISCED 1997. Retrieved from http://www.uis.unesco.org/Library/Documents/isced97-en.pdf

US Bureau of Labor Statistics. (2000). Table 8. Employed and unemployed full- and part-time workers by age, sex, and race. Retrieved from http://www.bls.gov/cps/aa1999/CPSAAT8.pdf

Van Buuren, S., Brand, J. P. L., Groothuis-Oudshoorn, C. G. M., \& Rubin, D. B. (2006). Fully conditional specification in multivariate imputation. Journal of Statistical Computation and Simulation, 76(12), 10491064. http://dx.doi.org/10.1080/10629360600810434

Ware, J. H., \& Wu, M. C. (1981). Tracking: Prediction of Future Values from Serial Measurements. Biometrics, 37(3), 427-437. http://dx.doi.org/10.2307/2530556

Warner, D., \& Hofmeister, H. (2006). Late Career Transitions among Men and Women in the United States. In H.P. Blossfeld, S. Buchholz, \& D. Hofäcker (Eds.), Globalization, Uncertainty, and Late Careers in Society (pp. 141-181). New York: Routledge.

White, I. R., Royston, P., \& Wood, A. M. (2011). Multiple imputation using chained equations: Issues and guidance for practice. Statistics in Medicine, 30(4), 377-399. http://dx.doi.org/10.1002/sim.4067 
Williamson, J. B., \& McNamara, T. K. (2003). Interrupted Trajectories and Labor Force Participation. Research on Aging, 25(2), 87-121. http://dx.doi.org/10.1177/0164027502250015

Wilmoth, J., \& Koso, G. (2002). Does Marital History Matter? Marital Status and Wealth Outcomes among Preretirement Adults. Journal of Marriage and Family, 64(1), 254-268. http://dx.doi.org/10.1111/j.1741$\underline{3737.2002 .00254 . x}$ 